\title{
Factors Associated with Populations of Plant-Parasitic Nematodes in Bentgrass Putting Greens in Oklahoma
}

\author{
N. R. Walker, Department of Entomology and Plant Pathology; C. L. Goad, Department of Statistics; H. Zhang, \\ Department of Plant and Soil Sciences; and D. L. Martin, Department of Horticulture and Landscape Architecture, \\ Oklahoma State University, Stillwater 74078
}

\begin{abstract}
Walker, N. R., Goad, C. L., Zhang, H., and Martin, D. L. 2002. Factors associated with populations of plant-parasitic nematodes in bentgrass putting greens in Oklahoma. Plant Dis. 86:764768.

Numerous genera of plant-parasitic nematodes are frequently present at high populations in golf course putting greens. The objectives of this research were to identify and quantify plant-parasitic nematodes from Oklahoma bentgrass putting greens and to characterize specific soil physical and chemical features and management factors that may account for differences in or associated with the observed nematode populations. In the fall of 2000, nematodes were identified from 99 individual bentgrass putting greens sampled from 46 different locations in Oklahoma. In addition to green age and bentgrass cultivar; soil $\mathrm{pH}$, nitrate-nitrogen $\left(\mathrm{NO}_{3}-\mathrm{N}\right)$, plant-available phosphorus and potassium, organic matter $(\mathrm{OM})$, bulk density, and particle size distribution were determined for each green. Expenditures on management activities, including fertilizer, herbicide, fungicide, and insecticide, were determined for 20 of the sampled courses and compared with nematode populations. Nematodes from seven genera were found in Oklahoma greens, with Criconemella spp. being the most common. Paratrichodorus spp., Tylenchorhynchus spp., and Helicotylenchus spp. also were common. The logarithmic populations of all nematodes combined increased with greater green age $(r=0.37)$. A negative relationship was observed between soil bulk density and all nematodes combined $(r=-0.29)$. Soil $\mathrm{NO}_{3}-\mathrm{N}$, plantavailable $\mathrm{K}$, and $\mathrm{OM}$ increased with combined logarithmic populations of all plant parasitic nematodes ( $r=0.23,0.28$, and 0.37 , respectively). A four-factor model accounted for $75 \%$ of the total variation in the data and permitted groupings of all variables into four uncorrelated factors. Total logarithmic nematode populations increased with fungicide and herbicide expenditures $(r=0.31)$. This study suggests that populations of plant-parasitic nematodes may be influenced by the putting green abiotic soil environment and possibly indirectly by management practices on putting greens.
\end{abstract}

Additional keywords: Agrostis palustris, bulk density, Criconemella, Helicotylenchus, Hoplolaimus, Paratrichodorus, Tylenchorhynchus

Creeping bentgrass (Agrostis palustris Huds.) is an important component of putting greens in the southern United States. To achieve a high-quality putting surface, bentgrass is maintained at very low heights $(<4 \mathrm{~mm})$ and is grown in a root zone predominately composed of sand or a sandpeat mixture (19). Although tolerant of low mowing heights, bentgrass green quality can be reduced by hot temperatures, resulting in a reduction in root growth and subsequent recovery from wear or disease. To

Corresponding author: N. R. Walker

E-mail: walkenr@okstate.edu

Published with the approval of the Director, Oklahoma Agricultural Experiment Station, Stillwater. This project was supported in part by the Oklahoma Integrated Pest Management Program and the Oklahoma Agricultural Experiment Station project 2420 .

Accepted for publication 1 March 2002.

Publication no. D-2002-0510-01R

(C) 2002 The American Phytopathological Society maintain a high-quality putting surface, greens are intensely managed with pesticides, fertilizer, and irrigation to prevent disease, damage from wear, and deficiencies in fertility and moisture, and to minimize deleterious effects due to extremes in environmental conditions. In spite of efforts to maintain turf density, vigor, quality, and disease suppression, greens often fail to respond to management inputs and to maintain a desirable putting surface. This often occurs during warm periods, when use is frequent and environmental conditions are conducive for disease. These conditions often are present when plantparasitic nematodes are present at their highest populations (17).

Plant-parasitic nematodes are important yield-reducing pests of most agronomic crops worldwide. Nematodes typically feed on subterranean plant tissues, including roots, tubers, and rhizomes. Feeding rarely causes plant death; however, nematodes can arrest root growth and cause lesions, necrosis, or impaired root function. For agronomic crops, affected plants are chlorotic, stunted in growth, have lower yields, and often are more susceptible to diseases caused by facultative microbes. Turf grass growth can be stunted by nematodes and stands of turf can become less dense. For specific nematode-turf combinations, the affected turf grass may die. In addition, large numbers of plant-parasitic nematodes in a bentgrass putting green may interfere with the effectiveness of management inputs, such as nutrient uptake by plants.

Plant-parasitic nematodes from numerous genera often are present in putting greens. Helicotylenchus, Criconemella, Hoplolaimus, and Tylenchorhynchus spp. were found in $55,52,47$, and $38 \%$, respectively, of 81 greens from 20 Kansas golf courses (18). Mean nematode populations in the study were $425,900,81$, and $242 / 100 \mathrm{~cm}^{3}$ soil for Helicotylenchus, Criconemella, Hoplolaimus, and Tylenchorhynchus spp., respectively. Similar results were found in an earlier study conducted in New York in which Criconemella, Tylenchorhynchus, Hoplolaimus, and Helicotylenchus spp. were present in 78, 71, 55 , and $39 \%$, respectively, of 295 samples collected from 16 golf courses; however, mean population values were not reported (11).

Fluctuations or distribution differences of nematode populations are common in turfgrass ecosystems. Fluctuating populations of Belonolaimus longicaudatus parasitizing Bermudagrass in California were correlated with soil temperatures $\left(r^{2}=\right.$ 0.40) (2). In Illinois, Tylenchorhynchus nudus, Helicotylenchus cornurus, and Criconemella curvata were more frequently recovered from the upper $2.5 \mathrm{~cm}$ of a bentgrass putting green than from 2.5- to 5.0cm depths (4). However, in New England, nematode populations were not found to be consistent within a green over time (23).

The effect of individual and combined populations of plant-parasitic nematodes on bentgrass root and shoot growth has been characterized. In greenhouse studies, only mixed populations of Hoplolaimus spp. and T. dubius reduced shoot growth and caused bentgrass leaf chlorosis (9). A similar reduction in shoot growth was observed for mixed populations of Pratylenchus penetrans and T. agri, but not for individual nematode species (15). The effects of plant-parasitic nematodes on bentgrass plants in situ has been more dif- 
ficult to characterize due to variable factors such as temperature, damage from other diseases, and green construction.

Effective management of plant-parasitic nematodes in existing bentgrass greens is limited to applications of organophosphorous pesticides. Concerns about organophosphorous pesticide safety and fate in the environment could potentially limit their use on golf courses. Older greens that do not provide acceptable turfgrass quality are either fumigated or rebuilt using new root zone media. These disruptive management options usually are reserved until the accumulation of organic matter or presence of plant pathogens are thought to be too high to be managed by standard management practices such as the removal of numerous, small soil cores (aerification) prior to the application of sand to the surface of the green.

The sand-based root zone, continual presence of plants, and absence of fluctuating soil water content likely encourage an increase in populations of plant-parasitic nematodes. However, communities of plant-parasitic nematodes in bentgrass greens from the same region can differ dramatically (21). Previous studies of nematode distribution in bentgrass greens have not examined factors which could account for differences in nematode populations. The objectives of this research were to identify and quantify plant-parasitic nematodes from Oklahoma bentgrass putting greens and to characterize specific soil physical and chemical features and maintenance expenditures that may account for differences in or are associated with the observed nematode populations in the greens sampled.

\section{MATERIALS AND METHODS}

From September through the first week of November 2000, soil samples were collected from 99 bentgrass putting greens from 43 golf courses and 3 research facilities in Oklahoma. Samples, one from each green, were collected with a cup cutter (10.8 $\mathrm{cm}$ in diameter) to a depth of about $10 \mathrm{~cm}$. Green age and bentgrass cultivar were recorded at the time of sampling for each green. Soil samples were stored $(<2$ weeks) at $4^{\circ} \mathrm{C}$ and thatch was removed prior to analysis. Nematodes were extracted from a $100-\mathrm{cm}^{3}$ subsample of soil by sieving and centrifugal floatation (1). Plant-parasitic nematodes were identified to genus, and total populations from 100 $\mathrm{cm}^{3}$ of soil were determined using a compound light microscope.

A portion of each soil sample ( $>200$ $\mathrm{cm}^{3}$ ) assayed for nematodes was air dried on a greenhouse bench for a minimum of 1 week, ground with a rotary impact grinder, and sieved $(<2 \mathrm{~mm})$. All samples were analyzed for $\mathrm{pH}$, nitrate-nitrogen $\left(\mathrm{NO}_{3}-\mathrm{N}\right)$, plant-available phosphorus $(\mathrm{P})$ and potassium $(\mathrm{K})$, and soil organic matter $(\mathrm{OM})$. Soil $\mathrm{pH}$ was measured by glass electrode in a 1:1 soil:water suspension (16). Soil $\mathrm{NO}_{3}-$ $\mathrm{N}$ was extracted with $1 \mathrm{M} \mathrm{KCl}$ solution and quantified by the cadmium reduction method (7). Plant-available $\mathrm{P}$ and $\mathrm{K}$ were extracted using the Mehlich 3 solution (10). Soil OM was determined from organic carbon (C) using a dry combustion $\mathrm{C}$ analyzer (12) and a conversion factor of 1.724 (based on organic matter containing $58 \% \mathrm{C}$ ).

To determine soil bulk density and the distribution of sand particle sizes, a separate soil subsample $\left(31 \mathrm{~cm}^{3}\right)$ was dried for $24 \mathrm{~h}$ at $70^{\circ} \mathrm{C}$ in a forced-air oven and then weighed. Samples then were heated to $510^{\circ} \mathrm{C}$ in a furnace for $24 \mathrm{~h}$ to remove organic matter. Dry sand fractions were separated into United States Department of Agriculture-defined limits for basic soil textural classes by vibrating for at least 1 min on nested sieves of 2,000, 1,000, 500, 250,106 , and $53 \mu \mathrm{m}$ over a pan (3). Sand fractions collected on each sieve and silt with clay fraction collected inside the pan were weighed.

For all samples, nematode populations were transformed to a $\log _{10}(X+1)$ scale for analysis and the relationship between population densities for individual and total nematodes and soil factors were assessed by correlation analysis using SAS (SAS Institute, Cary, NC). The relationship between golf course expenditures (5) on fertilizer, herbicide, fungicide, insecticide, adjuvant, sand applications, and nematode populations was assessed by correlation analysis for a subsample of 20 different golf courses from which 43 greens were

Table 1. Plant-parasitic nematode genera present in bentgrass putting greens in Oklahoma

\begin{tabular}{lccc}
\hline Genera $^{\mathbf{a}}$ & $\mathbf{G r e e n s}_{\mathbf{( \% )}}^{\mathbf{b}}$ & Mean/100 $\mathbf{~ c m}^{\mathbf{3}} \mathbf{s o i l}^{\mathbf{c}}$ & $\mathbf{S E M}^{\mathbf{d}}$ \\
\hline Criconemella & 59.2 & 968 & 167 \\
Tylenchorhynchus & 47.6 & 460 & 94 \\
Paratrichodorus & 57.3 & 89 & 13 \\
Helicotylenchus & 32.0 & 727 & 355 \\
Pratylenchus & 16.2 & 126 & 43 \\
Hemicycliophora & 20.4 & 177 & 55 \\
Hoplolaimus & 5.8 & 164 & 92 \\
\hline
\end{tabular}

${ }^{a}$ Nematodes were collected from 99 greens at 46 locations in the fall of 2000. Populations were determined for $100 \mathrm{~cm}^{3}$ of soil by sieving and centrifugal floatation.

${ }^{\mathrm{b}}$ Percent of greens containing respective nematode.

${ }^{c}$ Mean number of nematodes based on greens having the respective nematode.

${ }^{\mathrm{d}}$ Standard error of the mean. sampled. These 20 courses varied in maintenance expenditures. Only significant correlation coefficients $(P \leq 0.05)$ are presented. To determine the effect of bentgrass cultivar on nematode populations, samples containing only the cultivars Penncross (Tee-2-Green Corp., Canby, OR) and SR1020 (Seed Research of Oregon Inc., Corvalis, OR) were selected for analysis of variance. To identify underlying factors responsible for correlations among variables, factor analysis on the soil variables was performed using SAS/FACTOR procedure (SAS Institute). Principle component analysis was first used for factor extraction and all factors with an eigenvalue greater than one were subjected to orthogonal rotation using varimax rotation (SAS Institute). The variables used were $\mathrm{pH}, \mathrm{NO}_{3}-\mathrm{N}$, plant-available $\mathrm{P}$ and $\mathrm{K}, \mathrm{OM}$, bulk density, percent sand, and particle size distributions.

\section{RESULTS}

The two most common bentgrass cultivars planted were Penncross and SR1020, which were grown on 34 and $31 \%$ of the greens sampled, respectively. Bentgrass mixtures, Pennlinks (Tee-2-Green Corp.), and Penn A-4 (Tee-2-Green Corp.) were present on 8,6 , and $6 \%$ of the greens, respectively. Five additional cultivars were present on the remaining $15 \%$ of greens.

Plant-parasitic nematodes from seven genera were identified in Oklahoma bentgrass putting greens (Table 1). Criconemella spp. were found most frequently and had the greatest population densities in greens where this nematode was present. In $28 \%$ of the greens with Criconemella spp., its populations were above $1,000 / 100 \mathrm{~cm}^{3}$ of soil. Paratrichodorus was the second most frequent nematode genus found in samples. However, population densities of this nematode genus were generally the lowest of those nematodes present in greens. Tylenchorhynchus spp. also were present in nearly half of the greens sampled. Although Helicotylenchus spp. were present in only $32 \%$ of greens, population densities were usually high.

The average age of putting greens sampled was 12.8 years. Total combined population densities of plant-parasitic nematodes increased with green age $(r=0.37)$. Individual populations of Criconemella, Tylenchorhynchus, and Helicotylenchus spp. also increased with green age (Table 2). $\mathrm{NO}_{3}-\mathrm{N}$, plant-available $\mathrm{P}$ and $\mathrm{K}$, and $\mathrm{OM}$ in the soil also increased with increasing green age $(r=0.34,0.31,0.26$, and 0.74 , respectively).

Soil $\mathrm{pH}$ ranged from 5.6 to 8.8 , with an average of 7.4. However, $\mathrm{pH}$ was not correlated with individual or combined nematode population densities. Numbers of Criconemella and Tylenchorhynchus spp. increased with increasing $\mathrm{NO}_{3}-\mathrm{N}$ content of greens. Populations of Criconemella, Tylenchorhynchus, and Helicotylenchus 
spp. increased with greater plant-available $\mathrm{P}$ and $\mathrm{K}$, and $\mathrm{OM}$ content. A negative relationship was observed between soil bulk density $\left(0.85\right.$ to $1.75 \mathrm{~g} / \mathrm{cm}^{3}, 1.21 \mathrm{~g} / \mathrm{cm}^{3}$ average) and populations of Paratrichodorus, Helicotylenchus, and combined populations of plant parasitic nematodes $(r$ $=-0.28,-0.27$, and -0.29 , respectively). In addition, only $\mathrm{NO}_{3}-\mathrm{N}$, plant-available $\mathrm{K}$, and $\mathrm{OM}$ increased with population densities of all plant-parasitic nematodes combined $(r=0.23,0.28$, and 0.37 , respectively).

Soil samples were composed primarily of sand $(85.2$ to $98.9 \%, 94.7 \%$ average) and particle size distribution was primarily limited to particles less than $1 \mathrm{~mm}$ in diameter and greater than $106 \mu \mathrm{m}$ in diameter (>2 mm, $0.95 \% ; 1 \mathrm{~mm}$ to $2 \mathrm{~mm}, 6.5 \%$; $500 \mu \mathrm{m}$ to $1 \mathrm{~mm}, 24.3 \%$; 250 to $500 \mu \mathrm{m}$, $40.1 \%$; 106 to $250 \mu \mathrm{m}, 20.4 \%$; 53 to 106 $\mu \mathrm{m}, 2.4 \%$ ). Population densities of Hoplolaimus spp. were negatively correlated with the percentage of sand fraction between $500 \mu \mathrm{m}$ and $1 \mathrm{~mm}(r=-0.22)$. Populations of Hoplolaimus and Criconemella spp. increased as the percent of sand frac- tion between 106 and $250 \mu \mathrm{m}$ in diameter increased ( $r=0.20$ and 0.21 , respectively). Total populations of plant-pathogenic nematodes decreased as sand fractions greater than $1 \mathrm{~mm}$ increased $(r=-0.26[1$ $\mathrm{mm}]$ and -0.21 [2 $\mathrm{mm}]$, respectively).

Populations of Criconemella spp., Tylenchorhynchus spp., and all combined plant-parasitic nematodes were greater in greens planted with cv. Penncross $(P \leq$ $0.001)$. However, the age of greens planted with the bentgrass cv. Penncross was, on average, 12.6 years older than greens planted with SR1020 bentgrass $(P \leq$ 0.0001).

In the factor analysis, eigenvalues for the first four factors were greater than one and accounted for $75 \%$ of the total variation for the soil variables (Table 3). The first factor accounted for $33.8 \%$ of the total variation in the soil variables, and had high positive factor loading on the 106- to 250$\mu \mathrm{m}$ sand fraction grouping, moderate loadings for $\mathrm{N}$ and $\mathrm{K}$, and negative loadings for the fraction groupings between 0.5 and 2 $\mathrm{mm}$ in diameter (Table 3). The second factor accounted for $17.9 \%$ of the total

Table 2. Values and correlation coefficients for soil factors and nematode populations from bentgrass putting greens in Oklahoma

\begin{tabular}{|c|c|c|c|c|c|}
\hline & \multirow[b]{2}{*}{$\begin{array}{c}\text { Green age } \\
\text { (years) }\end{array}$} & \multicolumn{3}{|c|}{ Factors (kg/ha) } & \multirow[b]{2}{*}{$\begin{array}{c}\text { Organic } \\
\text { matter }(\%)\end{array}$} \\
\hline & & $\mathrm{NO}_{3}-\mathrm{N}^{\mathrm{a}}$ & $\begin{array}{l}\text { Mehlich 3, } \\
\mathbf{P}^{\mathbf{b}}\end{array}$ & $\underset{\mathbf{K}^{\mathbf{b}}}{\text { Mehlich 3, }}$ & \\
\hline Mean $^{\mathrm{d}}$ & 12.8 & 14.3 & 105.1 & 167.6 & 1.51 \\
\hline Minimum & 0.5 & 3.4 & 12.5 & 43.1 & 0.07 \\
\hline \multirow[t]{2}{*}{ Maximum } & 60 & 104.4 & 452.9 & 808.1 & 7.37 \\
\hline & \multicolumn{5}{|c|}{ Correlation coefficients ${ }^{\mathrm{e}}$} \\
\hline Criconemella & 0.24 & 0.27 & 0.36 & 0.33 & 0.36 \\
\hline Tylenchorhynchus & 0.31 & 0.30 & 0.46 & 0.45 & 0.50 \\
\hline Helicotylenchus & 0.33 & NS & 0.39 & 0.30 & 0.34 \\
\hline
\end{tabular}

a Determined by extraction with $1 \mathrm{M} \mathrm{KCl}$ solution and quantified by the cadmium reduction method; $\mathrm{NO}_{3}-\mathrm{N}=$ nitrate-nitrogen.

${ }^{\mathrm{b}}$ Determined by extraction using Mehlich 3 solution; $\mathrm{P}=$ phosphorus, $\mathrm{K}=$ potassium.

${ }^{c}$ Determined using a dry combustion carbon analyzer.

d Nematodes were collected from 99 greens at 46 locations in the fall of 2000. Populations were determined for $100 \mathrm{~cm}^{3}$ of soil by sieving and centrifugal floatation and transformed prior to analysis $\log ^{10}(X+1)$.

e $r$ values significant at $P \leq 0.05, \mathrm{NS}=$ not significant.

Table 3. Rotated factor loadings and communalities of a four-factor model for physical and chemical soil properties of golf course putting greens and plant-parasitic nematode populations

\begin{tabular}{lccccc}
\hline & \multicolumn{4}{c}{ Factor loadings } & \\
\cline { 2 - 5 } Soil variable & $\mathbf{1}$ & $\mathbf{2}$ & $\mathbf{3}$ & $\mathbf{4}$ & Communalities \\
\hline $\mathrm{pH}$ & 0.25 & -0.75 & 0.01 & 0.19 & 0.66 \\
Nitrogen & 0.54 & 0.37 & 0.18 & 0.30 & 0.55 \\
Phosphorus & 0.26 & 0.62 & -0.10 & 0.25 & 0.53 \\
Potassium & 0.50 & 0.53 & -0.39 & 0.01 & 0.68 \\
Organic matter & 0.22 & 0.76 & -0.11 & 0.01 & 0.64 \\
Bulk density & 0.20 & 0.73 & -0.01 & -0.19 & 0.61 \\
Percent sand & 0.07 & -0.28 & 0.84 & 0.23 & 0.84 \\
Fraction & & & & & \\
$>2 \mathrm{~mm}$ & -0.21 & -0.09 & 0.05 & 0.86 & 0.79 \\
$1-2 \mathrm{~mm}$ & -0.75 & -0.09 & -0.15 & 0.59 & 0.93 \\
$0.5-1 \mathrm{~mm}$ & -0.84 & -0.15 & 0.10 & 0.34 & 0.85 \\
$250-500 \mu \mathrm{m}$ & 0.12 & -0.003 & 0.81 & -0.50 & 0.92 \\
$100-250 \mu \mathrm{m}$ & 0.90 & 0.11 & -0.20 & -0.09 & 0.87 \\
$50-100 \mu \mathrm{m}$ & 0.46 & -0.05 & -0.81 & -0.06 & 0.87 \\
Eigenvalues & 4.38 & 2.34 & 1.79 & 1.23 & $\ldots$ \\
Proportion of total $\mathrm{S}^{2}$ & 33.8 & 17.9 & 13.8 & 9.5 & $\ldots$ \\
\hline
\end{tabular}

variation for the soil variables and had moderate to high positive loadings for $\mathrm{pH}$, plant-available $\mathrm{P}$ and $\mathrm{K}$, bulk density, and OM. The third factor accounted for $13.8 \%$ of the total variation for the soil variables and had high positive loadings for percent sand and sand fraction between 250 and $500 \mu \mathrm{m}$ in diameter and a high negative loading for the fraction between 53 and $106 \mu \mathrm{m}$. The fourth factor accounted for $9.5 \%$ of the total variation in the soil variables and had high positive loading for only the fraction greater than $2 \mathrm{~mm}$. In regard to communalities (the percent of the variance of each variable accounted for by the factor analysis), the four-factor model explained nearly $80 \%$ or better the variance for percent sand and all sand fraction distribution groups (Table 3). However, the four-factor model only explained 53 to $68 \%$ of the variance for the soil factors, $\mathrm{NO}_{3}-\mathrm{N}$, plant-available $\mathrm{P}$ and $\mathrm{K}, \mathrm{pH}$, bulk density, and OM.

Factor analysis separated the set of highly correlated soil characteristic variables into four uncorrelated (orthogonal) factors. Using the factor scores associated with these four factors, a regression analysis was performed to model the populations of plant-parasitic nematodes from golf course putting greens based on the information in the soil characteristic variables. Each of the four factors was termed cpg1 (factor 1), cpg2 (factor 2), cpg3 (factor 3 ), and cpg4 (factor 4), where the respective factors were described previously. By using the factor scores associated with these factors in a regression analysis, multicollinearity problems inherent in the data are avoided. The resulting regression equation was obtained: $\log$ population $=2.36+$ 0.208 cpg $1+0.368 \operatorname{cpg} 2-0.225 \operatorname{cpg} 4\left(r^{2}=\right.$ $0.25)$.

Fertilizer, insecticide, adjuvant, and coring or sand application expenditures did not correlate with total population densities of plant-parasitic nematodes (data not shown). Total plant-parasitic nematode populations increased with fungicide and herbicide expenditures $(r=0.31$ and 0.43 , respectively). Numbers of Criconemella spp. increased with expenditures on adjuvant, fungicide, coring or sand application, and herbicide (Table 4). Populations of Tylenchorhynchus spp. increased only with increases in herbicide expenditures, whereas populations of Paratrichodorus spp. increased with all expenditures. In contrast, numbers of Helicotylenchus spp. were not correlated with any golf course expenditures.

\section{DISCUSSION}

Plant-parasitic nematodes were common in Oklahoma bentgrass putting greens. These results are consistent with those from other studies throughout the United States $(4,8,11,13)$. Criconemoides spp. were the most common nematodes found in these studies, as was the case in New 
York and Ohio putting greens $(11,14)$. Nematode populations have been reported to vary among golf courses and greens from a single course (21). Nematode populations also varied considerably among the greens sampled in this study (data not shown). Greenhouse studies with the bentgrass cvs. Penncross, SR1020, and Pennlinks ( $70 \%$ of the cultivars sampled) indicated that population densities of $T y$ lenchorhynchus spp. were not affected by turf grass cultivar (22). However, population densities of nematodes were different for the two prominent cultivars sampled in this study. This probably is due to the greater age of Penncross-planted greens, not differences in bentgrass cultivars.

Increasing nematode populations, OM, and plant-available $\mathrm{P}$ and $\mathrm{K}$ were correlated with greater green age. The correlation of these variables with age probably is a result of applications of fertilizers which contain $\mathrm{P}$ and $\mathrm{K}$ and plant growth which results in the accumulation of organic matter in greens over time. In Oklahoma, new greens usually are constructed of sand which may contain a few free-living but rarely plant-parasitic nematodes. The greater nematode populations found in older greens is probably a result of nematodes first becoming established and, subsequently, populations increasing over time.

Soil texture has been documented to influence plant-parasitic nematode populations. Numerous studies conducted with soils differing in texture have demonstrated the influence of soil physical characteristics on nematode population density $(20,22)$. For example, Rotylenchulus reniformis populations were higher than Meloidogyne incognita for soils having less sand (6). The mechanism of influence was suggested to be not a result of nematode exclusion but rather one which favors populations that have a competitive advantage over another species (6). The uniform sand mixture contained in a putting greens does not permit studies of soil texture but rather soil particle size, bulk density, and chemical differences as possible factors in the differences in nematode populations. A limited influence of sand particle size on nematode populations was found in this study. Although negative relationships were present between nematode population densities and fractions greater than $1 \mathrm{~mm}$, this represents less than $10 \%$ of the total soil particles present in greens in this study and can be considered to have a limited effect on nematode populations.

The results of this study indicate that bulk density appears to have an adverse impact on nematode populations. Differences in bulk density could by attributed to the particle size distribution of sands used in green construction and an increase over time as a result of compaction. The mechanism by which bulk density adversely affects nematode population density in greens is not known, but it may be caused by a greater water-holding capacity of the soil, resulting in a decrease in nematode activity.

Factor analysis, a method to identify underlying factors that are responsible for the correlation among variables, can be used to identify relationships and make interpretations not resulting from univariate analysis. Because the factors are orthogonal to each other, it is possible to identify the independent effects each abiotic variable has on nematode populations. The loading of all soil factors with the exception of particle size on two factors suggests their importance in affecting nematode populations. However, communalities estimated the portion of variance from each variable that was explained by the four-factor model, and the communalities for these variables were low, which indicates that much of the variable's variance is not explained. In contrast, the particle size grouping for sand loaded on all factors; however, these loadings were very high and the communalities indicate that most of the variance was explained.

Golf courses vary greatly in the intensity of greens maintenance due to budgetary allowances. It has been suggested that the high irrigation, pesticide, and fertilizer inputs that bentgrass putting greens receive may reduce the detrimental effects of nematodes on turf grasses $(11,18)$. The correlation between nematode densities and expenditures on herbicide and fungicide might support this suggestion, given

Table 4. Correlation coefficients $(r)$ for golf course maintenance expenditures and plant-parasitic nematode population densities.

\begin{tabular}{|c|c|c|c|c|c|c|}
\hline \multirow[b]{2}{*}{ Genera $^{a}$} & \multicolumn{6}{|c|}{ Expenditures } \\
\hline & Adjuvants & Fertilizer & Fungicide & Herbicide & Insecticide & Sand $^{\mathrm{b}}$ \\
\hline & \multicolumn{6}{|c|}{ Correlation coefficients $^{c}$} \\
\hline Criconemoides & 0.35 & NS & 0.40 & 0.51 & NS & 0.34 \\
\hline Tylenchorhynchus & NS & NS & NS & 0.37 & NS & NS \\
\hline Paratrichodorus & 0.51 & 0.51 & 0.43 & 0.36 & 0.36 & 0.47 \\
\hline Helicotylenchus & NS & NS & NS & NS & NS & NS \\
\hline
\end{tabular}

a Nematodes were collected from 43 greens at 20 locations in the fall of 2000. Populations were determined for $100 \mathrm{~cm}^{3}$ of soil by sieving and centrifugal floatation and transformed prior to analysis $\log _{10}(X+1)$.

${ }^{\mathrm{b}}$ Aerification prior to application of sand to the surface of the green.

${ }^{\mathrm{c}} r$ values significant at $P \leq 0.05, \mathrm{NS}=$ not significant. the assumption that the greater the financial expenditure the greater the intensity of greens maintenance and ability of the manager to react to the nematode damage. The correlation between $\mathrm{NO}_{3}-\mathrm{N}$ and nematode densities suggests that the higher $\mathrm{NO}_{3}-\mathrm{N}$ content in green soils is the result of greater $\mathrm{N}$ use by the greens manager to offset the effects of low-vigor greens containing high nematode populations. However, it is difficult to determine if management activities, such as fertilization, are in response to high nematode populations or attributed to high nematode populations, or if management activities possibly aid plants in supporting higher nematode populations without a reduction in turf grass quality.

\section{ACKNOWLEDGMENTS}

We thank C. E. Martin for technical assistance with this study.

\section{LITERATURE CITED}

1. Ayoub, S. M. 1980. Plant Nematology: An agricultural training aid. NemaAid Publications, Sacramento, CA.

2. Bekal, S., and Becker, J. O. 2000. Population dynamics of the sting nematode in California turf grass. Plant Dis. 84:1081-1084.

3. Blake, G. R., and Hartage, K. H. 1986. Particle density. In: Methods of Soil Analysis. Part 1. Physical and Mineralogical Methods. SSSA Book Ser: 9. A. Klute, ed. SSSA and ASA, Madison, WI.

4. Davis, R. F., Wilkinson, H. T., and Noel, G. R. 1994. Vertical distribution of three nematode genera in a bent grass putting green in central Illinois. J. Nematol. 26:518-521.

5. Duxbury, D., Martin, D., Woods, M., Willoughby, C., Wooten, M., Bloyd, B., and Maloney, R. 1998. 1996 Oklahoma golf course maintenance cost survey. Okla. Agric. Stat. Serv., Stillwater, OK.

6. Koenning. S. R., Walters, S. A., and Barker, K. R. 1996. Impact of soil texture on the reproduction of Rotylenchulus reniformis and Meloidogyne incognita on cotton. J. Nematol. 28:527-536.

7. LACHAT. 1994. QuickChem Method 12-10704-1-B. LACHAT Instrument, Milwaukee, WI.

8. Lucas, L. T., Blake, C. T., and Barker, K. R. 1974. Nematodes associated with bent grass and Bermuda grass golf greens in North Carolina. Plant Dis. Rep. 58:822-824.

9. Lukens, R. J., and Miller, P. M. 1973. Injury to turf grasses by Tylenchorhynchus dubius and Hoplolaimus spp. (Abstr.) Phytopathology 63:204.

10. Mehlich, A. 1984. Mehlich 3 soil test extractant: A modification of Mehlich 2 extractant Commun. Soil Sci. Plant Anal. 15:1409-1416.

11. Mudoch, C. L., Tashiro, H., and Harrison, M. B. 1978. Plant-parasitic nematodes associated with golf putting-green turf in New York. Plant Dis. Rep. 62:85-87.

12. Nelson, D. W., and Sommers. L. E. 1996. Total carbon, organic carbon, and organic matter. In: Methods of Soil Analysis. Part 3 Chemical Methods. SSSA Book Ser: 5. D. L. Sparks, ed. SSSA and ASA, Madison, WI.

13. Tashiro, H., Mudoch, C. L., and Apt. W. J. 1977. Plant-parasitic nematodes associated with golf putting-green turf in Hawaii. J. Nematol. 61:919-921.

14. Safford., J., and Riedel, R. M. 1976. Criconemoides species associated with golf course turf in Ohio. Plant Dis. Rep. 60:405408. 
15. Sikora, R. A., Taylor, D. P., Malek, R. B., and Edwards, D. I. 1971. Interaction of Meloidogyne nassi, Pratylenchus pentrans, and Tylenchorhynchus agri on creeping bent grass. J. Nematol. 4:162-165.

16. Sims, J. T. 1996. Lime requirement. Pages 491-515 in: Methods of Soil Analysis, Part 3. Chemical Methods. SSSA Book Ser: 5. D. L. Sparks, ed. SSSA and ASA, Madison, WI.

17. Smiley, R. W., Dernoeden, P. H., and Clarke, B. B. 1992. Compendium of Turf grass Disease. American Phytopathological Society Press, St. Paul, MN.
18. Todd, T. C., and Tisserat, N. A. 1990. Occurrence, spatial distribution, and pathogenicity of some phytoparasitic nematodes on creeping bent grass putting greens in Kansas. Plant Dis. 74:660-663.

19. USGA Green Section Staff. 1993. USGA recommendations for a method of putting green construction. Pages 1-3 in: The 1993 Revision. USGA Green Section Record, Far Hills, NJ.

20. Walker, N. W., and Martin, D. L. 2001. Effects of Tylenchorhynchus claytoni on creeping bent grass. (Abstr.) Phytopathology
91:S93.

21. Wallace, H. R. 1971. Abiotic influences in the soil environment. Pages 257-280 in: Plant Parasitic Nematodes. Vol. I. B. M. Zuckermann, W. F. Mai, and R. A. Rohde, eds. Academic Press, New York.

22. Wallace, H. R. 1973. Nematode Ecology and Plant Disease. Crane, Russak, New York.

23. Wick, R. L., and P. M. Vittum. 1988. Spatial and temporal distribution of plant parasitic nematodes in putting greens in the New England region. (Abstr.) Phytopathology 78:1521. 